\title{
PERAN PENDIDIK DALAM KONSEP PSIKOLOGI PERKEMBANGAN ANAK USIA DINI
}

\author{
Mawarni Purnamasari', Na'imah ${ }^{2}$ \\ Tarbiyah Keguruan, UIN Sunan Kalijaga ${ }^{1}$, Tarbiyah Keguruan, UIN Sunan Kalijaga ${ }^{2}$ \\ Email: mawarnipurnamasari@gmail.com ${ }^{1}$, Email: drnaimah24@gmail.com ${ }^{2}$ \\ Purnamasari, Mawarni., Na'imah. (2020). Peran Pendidik Dalam Konsep Psikologi Perkembangan \\ Anak Usia Dinil. Jurnal Pelita PAUD, 4(2), 295-303. \\ doi: https://doi.org/10.33222/pelitapaud.v4i1.990
}

\begin{abstract}
Abstrak: Penelitian ini bertujuan untuk menjelaskan peran pendidik dalam perkembangan anak usia dini. Tulisan ini mengulas mengenai peran pendidik dalam perkembangan dan pertumbuhan anak melalui konsep psikologi perkembangan. Pendekatan yang digunakan adalah kualitatif yang melibatkan peneliti studi pustaka (studi literatur). Hasil dari penelitian ini menunjukkan bahwa secara teoritik terdapat tiga teori terdahulu dalam perkembangan dan pertumbuhan anak, diantaranya adalah teori Piaget, teori Vygotsky, dan Bowlby. Menurut Piaget, anak usia dini memiliki pikiran yang pra-operasional dimana anak sudah mampu mengembangkan tindakan terstruktur untuk menghadapi lingkunganny. Selanjutnya menurut Vygotsky perkembangan anak pada masa menuju prasekolah didasari oleh jenis-jenis interaksi yang dimiliki anak di lingkungan sosialnya yang berpusat pada pencapaian tugas perkembangan. Dan menurut Bowlby dengan teorinya yaitu attachment (melekat) anak berkosentrasi pada kebutuhan mereka untuk mempertahankan kedekatannnya kepada orang tuanya atau pengasuhnya (termasuk pendidik). Terdapat banyak faktor yang menyebabkan pertumbuhan dan perkembangan anak, yaitu faktor internal (dalam) dan faktor eksternal (luar/lingkungan).
\end{abstract}

Kata kunci: anak usia dini, peran pendidik, psikologi perkembangan.

Abstract: This study aims to explain the role of educators in early childhood development. This paper reviews the role of educators in the development and growth of children through the concept of developmental psychology. The approach used is qualitative involving researchers of literature studies (literature studies). The results of this study indicate that theoretically there are three previous theories in child development and growth, including Piaget's theory, Vygotsky's theory, and Bowlby. According to Piaget, early childhood has a pre-operational mind where children are able to develop structured actions to deal with their environment. Furthermore, according to Vygotsky child development in the period leading to pre-school is based on the types of interactions that children have in their social environment which are centered on achieving developmental tasks. And according to Bowlby with his theory of attachment, children concentrate on their need to maintain closeness to their parents or caregivers (including educators). There are many factors that cause children's growth and development, namely internal (internal) and external (external / environmental) factors.

Keywords: early childhood, developmental psychology, the role of educators.

http://jurnal.upmk.ac.id/index.php/pelitapaud 


\section{PENDAHULUAN}

Anak memiliki pola tingkah laku yang unik, perilaku yang menarik, dan sering menarik perhatian orang sekitar seperti orang dewasa. Aktivitas anak dalam kehidupan sehari-hari beraneka ragam, sesuai dengan tingkat usianya masing-masing. Baik usia bayi, bayi dibawah tiga tahun (batita), bayi dibawah lima tahun (balita), anak usia TK (4-6 tahun), sampai pada anak usia sekolah dasar (SD). Semua tingkat usia tersebut dikelompokkan sebagai masa anak usia dini. Usia dini (0-6 tahun) merupakan usia dimana sangat menentukan bagaimana suatu karakter anak akan terbentuk, begitu pula dengan kepribadian anak. Karena masa usia dini merupakan usia emas (golden age) bagi anak mengalami pertumbuhan dan perkembangannya yang sangat pesat.

Pertumbuhan dan perkembangan seorang anak tidak lepas dari tanggung jawab orang tua, keluarga maupun pendidik. Orang tua dan keluarga adalah orang-orang terdekat dengan kehidupan anak sejak lahir dan memberi pengaruh yang sangat besar terhadap pertumbuhan dan perkembangan anak. Setelah anak memiliki umur yang cukup untuk masuk pada sekolah PAUD, maka orang yang berpengaruh selanjutnya adalah pendidik. Setiap anak memiliki potensi yang berbeda-beda pula. Vygotsky meyakini bahwa pengetahuan interaksi sosial anak merupakan hal yang penting bagi perkembangan dalam proses berpikir anak (Fakhruddin, 2010). Suatu pembelajaran akan menjadi pengalaman yang bermakna bagi anak jika ia dapat melakukan sesuatu atas lingkungannya.

Segala potensi anak, khususnya potensi inteligensi akan berkembang pesat tergantung pada orang tua dan pendidik (guru di sekolah), dan faktor pendukung lainnya. Pola asuh yang melekat adalah siapa yang paling dekat dengan seorang anak. Apabila yang paling dekat adalah ibu, maka watak ibu akan berpengaruh. Begitu pula bila ternyata pendidik di sekolah yang paling dekat, maka perilaku anak akan mengikuti gurunya. Beberapa orang tua menceritakan bahwa anaknya sering mengikuti sikap guru yang disukainya. Semakin anak menyukai gurunya, maka setiap perkataan dan tingkah laku gurunya juga diikuti (imitasi) oleh anak.
Menjadi pendidik yang bisa memberikan stimulasi, pendidikan, bimbingan, kasih sayang, motivasi, dan perhatian dalam proses pertumbuhan dan perkembangan anak didik, maka pendidik harus memiliki pemahaman tentang bagaimana pentingnya peran pendidik dalam konsep psikologi perkembangan anak.

Peran pendidik yang maksimal dan saling bekerja sama dengan orang tua secara positif akan menghasilkan anak yang luar biasa dalam potensi yang dimilikinya. Terwujudnya pertumbuhan dan perkembangan anak yang baik dikarenakan peran pendidik yang mengoptimalkan stimulasi pada semua aspek perkembangan yang dapat memunculkan potensi anak dalam pengasuhan yang dilakukan secara maksimal. Dengan demikian pendidik juga sangat berpengaruh dan bertanggung jawab terhadap perkembangan anak didik agar berguna bagi lingkungannya, dunia, dan masa depannya sehingga anak mampu berkembang sesuai dengan tahapan perkembangannya.

Beberapa penelitian sebelumnya menunjukkan bahwa peran pendidik dalam konsep psikologi perkembangan anak usia dini memiliki hubungan. Proses belajar seorang anak dimulai sejak menit-menit pertama dalam hidupnya. Murid atau peserta didik berkah mendapatkan pelayanan yang bermakna (meaningful), seperti lingkungan yang bermanfaat untuk proses belajar yang efektif (Leikin \& Dinur, 2011).

Maka dari itu, penelitian ini menunjukkan bahwa betapa pentingnya peran pendidik dalam kehidupan masa depan dan mengembangkan potensi anak usia dini. Selain orang tua, pendidik memberikan semua bimbingan, motivasi, kasih sayang dan stimulus pada semua aspek perkembangan anak. Penelitian ini tujuan yakni agar peran pendidik PAUD tidak lagi dipandang sebelah mata oleh masyarakat. Dalam penelitian ini juga peneliti ingin mengungkapkan bagaimana pendidik PAUD dapat berperan dengan baik sebagai agen pembelajaran dalam mengimplementasikan konsep psikologi perkembangan anak.

Salah satu komponen pedagogik pendidik / guru PAUD adalah memahami pengetahuan tentang psikologi perkembangan anak. Pendidik harus memahami dunia anak-anak. Pengetahuan tentang perkembangan anak 
dapat membantu anak dalam mengembangkan diri dan memecahkan masalah yang dihadapinya, melalui pemahaman tentang faktor-faktor yang memengaruhi perkembangan anak.

Pendidik merupakan sebutan untuk seorang yang mendidik (Setiawan, 2014). Dalam konteks penelitian ini yang dimaksud sebagai pendidik adalah guru Pendidikan Anak Usia Dini (PAUD). Dalam Permendikbud Nomor 137 Tahun 2014 tentang kompetensi pendidik PAUD dikatakan bahwa pendidik anak usia dini merupakan tenaga professional yang bertugas merencanakan, melaksanakan pembelajaran, dan menilai hasil pembelajaran, serta melakukan pembimbingan, pelatihan, pengasuhan dan perlindungan (Depdikbud, 2014).

Konsep psikologi perkembangan memiliki teori-teori yang menjelaskan tentang proses pertumbuhan dan perkembangan anak. Dalam penelitian ini, peneliti hanya mengambil tiga ahli yaitu Piaget, Vygotsky, dan Bowbly.

\section{Teori Piaget}

Piaget berpendapat bahwa anak usia dini merupakan pikiran yang pra-operasional. Dalam periode ini anak mampu mengembangkan tindakan yang baik dan terstruktur untuk menghadapi lingkungan, anak mulai memahami simbol yang digunakan dalam sebuah objek tertentu (Patilima, 2015). Dalam proses perkembangan anak menurut Piaget adalah proses secara genetik yang merupakan dasar dari mekanisme biologis dalam perkembangan bentuk syaraf. Semakin bertambah umur manusia maka semakin sempurna pula susunan syarafnya. Sehingga kemampuan yang dimilikinya akan mengalami peningkatan. Ketika seseorang mulai berkembang menuju tahap kedewasaan, maka akan mengalami adaptasi biologis terhadap lingkungannya yang akan menimbulkan perubahan-perubahan secara kualitatif di dalam struktur kognitifnya. Namun, Piaget tidak melihat perkembangan kognitif secara kuantitatif. Dengan demikian dapat ditarik kesimpulan bahwa setiap anak memiliki perkembangan yang berbeda sesuai dengan tingkatan usia dengan kekuatan mental dalam perkembangan secara kualitatif (S. Arifin, 2016, p. 52).
Jika terdapat keluarga yang memiliki anak berusia 0-2 tahun, maka anak tersebut harus dalam perhatian yang ekslusif dalam setiap perkembangannya. Menurut Piaget pada masa sensorimotor dan pra-operasional anak sangat berpengaruh dalam 0-2 tahun. Sebagai orang tua harus memperhatikan beberapa hal mencakup perkembangannya baik dalam pengawasan maupun dalam menjalankan perannya sebagai orang tua secara rinci dalam perkembangan kognitif seorang anak dalam tahap sensorimotor (Paul, 2001, p. 102). Berdasarkan hal tersebut, anak usia dini sedang berada pada tahap sensorimotor dan pra-operasional. Pada tahap sensorimotorik, bayi mengalami kemajuan dalam mengambil tindakan. Sedangkan tahap pra-operasional yang dimulai antara usia 2-7 tahun merupakan tahap kedua setelah tahap pertama dari Piaget. Dari tahap kedua, anak mulai memahami dunia dengan kata-kata dan gambar. Mereka mulai mengembangkan sebuah pemahaman yang stabil dan dapat melakukan penalaran (Pratiwi et al., 2017, p. 57).

Sejak awal kelahiran hingga sekitar usia dua tahun merupakan tahapan sensorimotor. Dimana pada tahapan ini seorang bayi mulai mampu memahami dunia dengan mengkoordinasikan pengalaman sensori mereka (seperti melihat dan mendengar) dengan gerakan (otot) mereka (menggapai dan menyentuh), maka dari itu diartikan sebagai tahap sensorimotor. Contoh dalam tahap sensorimotor menurut Piaget adalah bayi mulai mampu memahami lingkungan dengan menggunakan pengalaman penglihatannya dan tindakan fisik. Seorang bayi dapat dikatakan maju selangkah dari hari sebelumnya dan mengarah kepada tindakan pemikiran dan geraknya yang secara simbolik ke tahap akhir (John. W Santrock, 2010, p. 48). Dalam tahapan perkembangan sensorimotor anak sejak usia 0-2 tahun ditandai dengan pertumbuhan aspek kognitif yang mendasari pada perlakuan penglihatan dan gerakan. Tindakan pertama yang membentuk relasi secara refleks, mampu mengikuti tindakan orang yang berlalu, dan menyusun arti baru dalam pemecahan masalah dengan cara menggabungkan yang sebelumnya dengan pengetahuan. Dalam periode yang sangat singkat yaitu 2 tahun, anak telah mengubah dirinya dari organism 
yang sama sekali tergantunng dengan sifat bawaan menjadi orang yang mampu berfikir secara simbolis (Suyadi, 2010, p. 190). Dari uraian tahap sensorimotor tersebut, anak mulai mampu membentuk pengetahuannya sendiri, ia mampu mengasimilasi dan mengakomodasi sesuatu yang terjadi pada dirinya dalam lingkungannya untuk menunjukkan bahwa anak aktif mampu membentuk pengetahuan sejak lahir. Setiap stimulus yang diberikan oleh orang tuanya nanti akan menjadikan seorang anak untuk melakukan adaptasi yang sesuai dengan akomodasi maupun asimilasi yang bekerja dengan cepat untuk mempengaruhi perubahan-perubahan pada anak secara berkelanjutan. Dengan demikian, setiap perilaku maupun tingkah laku anak menunjukkan perkembangan pada aspek kognitif secara kualitas. Dalam perkembangan ini terjadi secara terus menerus dan bekelanjutan karena periode yang sebelumnya menjadi titik berat dalam perkembangan periode selanjutnya.

\section{Teori Vygotsky}

Vygotsky memandang bahwa perkembangan anak diawali pada masa awal yang menuju persiapan bersekolah didasari oleh jenis strategi yang dimiliki anak di lingkungan sosial maupun sekolahnya yang didasari oleh tugas pencapaian perkembangan anak. Pada zona perkembangan dekat (ZPD), Vygotsky memahami bahwa terdapat kerumitan relasi yang mencerminkan hubungan antara pembelajaran dengan perkembangan yang dinamis berbentuk siklus mental seorang anak yang memiliki manfaat bersama dalam bentuk tersendiri. ZPD yang digunakan oleh Vygotsky mendefinisikan bahwa perkembangan anak biasanya diartikan sebagai sebuah skala yang merupakan titiktitik dari hubungan dalam keterampilan dan kemampuan dalam sebuah kesatuan yang memiliki tingkat penguasaan yang berbedabeda. Namun, seiring dengan perkembangan seorang anak yang memiliki ZPD tidak tetap akan sering berubah-ubah dalam proses pembelajaran. Jika anak melakukan sesuatu pada dirinya untuk proses belajar dari berikutnya (Roopnarine \& Johnson, 2015, p. 248).

Batasan yang dimiliki oleh ZPD adalah batas bawah dan batas atas, yang dimana batas bawah dari ZPD yaitu tingkah permasalahan yang mampu dipecahkan oleh anak dengan sendirinnya. Sedangkan batas atas dari ZPD yaitu kemampuan tanggung jawab anak bertambah atau anak mampu menerima tugas tambahan dengan bantuan orang yang lebih mampu dari dirinya. Hal ini dapat dilaksanakan dengan cara scaffolding . Scaffolding adalah sebuah cara yang mampu mengubah level dalam dukungan tertentu. Artinya memberikan bantuan kepada anak selama tahap-tahap perkembangannya yang kemudian anak akan mengambil alih tanggung jawab yang semakin besari berkat dorongan, petunjuk, dan peringatan. Menurut Vygotsky, setiap anak yang memiliki banyak konsep dalam perkembangan tetapi belum sistematid, logis, dan rasional. Setiap percakapan antara anak dengan orang dewasa khususnya orang tua akan lebih memahami dalam membantu anak. Hal ini berlaku juga untuk pendidik di sekolah yang membantu dan memahami anak menjadi seorang yang lebih sistematis, logis, dan rasional. Anakanak harus dibiarkan secara bebas dan berkembang dengan bebas untuk mengetahui sesuatu yang belum diketahuinya.

Menurut Vygotsky, alat yang sangat berpengaruh dalam psikologis adalah ucapan. Karena ucapan mampu mengembangkan pikiran secara bebas dan perhatian pada pemahaman secara spontan. Selanjutnya Vygotsky berkata bahwa kebolehan untuk terlibat dalam percakapan secara batin terdapat tiga tahap, yaitu: a) Kesatu, merupakan tujuan kepada objek yang tidak berlangsung dalam hubungan timbal balik anak dengan orang lain; b) Kedua, ketika anak memasuki usia antara tiga tahun tahun atau lebih, ia lebih memfokuskan terhadap ucapan yang sama terhadap diri sendiri; c) Ketiga, saat usia delapan tahun keatas, ujaran atau ungkapan dalam hati anak sama sekali tidak dapat didengar. Artinya percakapan batin pada anak pun memiliki perkembangan pada setiap usianya.

\section{Teori Bowlby}

Bowlby dengan teorinya yaitu attachment (melekat) menyatakan ada 4 tahap perkembangan pada anak usia dini. Pada fase pertama, respon anak tidak terpilah (usia lahir sampai 3 bulan). Pada fase ini, bayi sangat menyukai wajah manusia dibandingkan 
dengan benda lainnya dan selalu tersenyum kepada semua orang yang dilihatnya. Artinya sikap yang ditunjukkan bayi ini adalah fakta kemelekatan bayi dengan semua orang yang ada di sekitarnya.

Fase kedua, usia 3-6 bulan, bayi hanya fokus pada wajah dan orang yang dikenalnya saja. Karena pada tahap ini, bayi akan lebih selektif dalam memberikan respon senyum. Bayi hanya tersenyum kepada orang-orang dikenalnya. Sikap ini menunjukkan kemelekatan bayi hanya dengan orang yang dikenalnya.

Selanjutnya pada fase ketiga, kemelekatan yang intens dan pencarian kedekatan yang aktif pada usia 6 bulan sampai 3 tahun. Pada fase ini bayi selalu menangis jika ditinggalkan ibunya, ia akan menunjukkan rasa cemas terhadap perpisahan. Bayi akan menangis jika ditinggalkan dan akan tersenyum jika ibunya kembali.

Dan terakhir yaitu fase keempat, usia 3 tahun sampai pada masa kanak-kanak anak akan mengalami masa tingkah laku persahabatan. Pada fase ini anak-anak berkonsentrasi pada kebutuhan mereka untuk mempertahankan kedekatannya kepada orang tuanya atau pengasuhnya (termasuk pendidik). Teori kemelekatan Bowlby menunjukkan bahwa manusia sejak anak-anak tidak bisa hidup sendirian sebagai makhluk sosial. (Jhon W. Santrock, 2011).

Dari beberapa tahapan dan fase yang diuraikan tersebut dapat disimpulkan bahwa proses dari tingkah laku anak memiliki perkembangan yang berbeda-beda sesuai dengan periode usia 0-6 tahun-tahun atau dari masa lahir sampai masa kanak-kanak akhir. Yang dimana pada masa kanak-kanak ini anak selalu memiliki hubungan dengan orang-orang sekitarnya, termasuk pendidik dalam membantu pertumbuhan dan perkembangannya.

\section{METODE PENELITIAN}

Penelitian ini adalah penelitian studi pustaka atau studi teks. Dalam penelitian studi pustaka atau studi teks mencakup beberapa bagian. Pertama telaah teori yang merupakan langkah disiplin ilmu yang perlu dilanjutkan secara empiris untuk memperoleh kebenaran secara empiris. Bagian berikutnya yaitu studi yang berupaya dalam mempelajari seluruh obyek penelitian secara teoritik yang terkait dengan validitas. Ketiga studi yang berupaya mempelajari teoritik linguistik. Kemudian keempat adalah studi karya sastra.

Adapun penelitian ini lebih kepada studi pustaka yang mengkaji peran pendidik dalam pertumbuhan dan perkembangan dalam teori psikologi perkembangan. Tentunya penelitian ini akan sedikit membantu bagi para pendidik agar lebih memahami bahwa terdapat teoriteori yang membahas pertumbuhan dan perkembangan anak usia dini dalam lingkupan psikologi perkembangan.

\section{HASIL PENELITIAN \\ PEMBAHASAN} DAN

\section{Analisis Teori Piaget}

Piaget mengemukakan tentang bagaimana anak belajar, "anak belajar melalui interaksi dengan lingkungannya". Anak belajar melalui interaksi dengan lingkungannya. Menurut Piaget anak seharusnya mampu melakukan percobaan dan penelitian sendiri. anak harus berani bereksperimen dan guru bisa menuntun anak-anak dengan menyediakan bahan-bahan yang tepat. Tetapi yang terpenting agar anak dapat memahami sesuatu, anak harus membangun pengertian itu sendiri dalam dirinya dan harus menemukannya sendiri.

Menurut Piaget anak lahir dengan segala keunikan dan potensi yang ada dalam dirinya, yang antara satu dengan yang lainnya tidaklah sama pada setiap anak, bahkan anak kembar sekalipun. Tugas orang tua, guru, dan orang dewasa yang lain adalah menyiapkan lingkungan yang memungkinkan potensipotensi yang dimiliki anak bisa berkembang dengan optimal baik potensi nalar (intelegensi), rasa (emosi), spiritual, maupun keterampilan (motorik dan seni). Pertumbuhan dan perkembangan anak selain didukung oleh adanya peran keluarga (orang tua), peran pendidik juga sangat penting di sini. Karena pendidik merupakan orang tua kedua bagi anak selama anak dititipkan di tempat penitipan anak ataupun selama anak dalam sekolah. Hubungan yang positif dan kerjasama yang baik antara orang tua dan pendidik harus berjalan dengan harmonis sehingga pertumbuhan dan perkembangan anak akan terstimulasi dengan optimal.

Selain itu, seorang pendidik harus menyadari bahwa anak memiliki tingkat ketertarikan dan 
model belajar yang berbeda dan pada waktu yang berbeda pula. Misalnya, seorang anak perempuan berada di tahapan berpikir konkret, ia mulai berfikir secara logis, tetapi sebagian dari pikirannya tidak terlepass dari objek-objek dan aktivitas-aktivitas yang konkret. Dengan demikian, pembelajaran semestinya memberi kesempatan besar untuk anak agar ia mampu menghadapi kegiatan secara nyata. Misalnya, jika seorang guru TK ingin mengajarkan anak didik tentang tanaman bunga, tidak seharusnya guru memberikan materi secara umum dan dengan bahasa yang tidak tepat dengan usia anak usia dini. Hal yang harus diakui oleh setiap pendidik adalah setiap anak tidak mudah dalam menemukan hal baru dalam pengalaman pendidikan yang paling mendasar. Dalam tahapan kognitif dapat membantu anak dalam pengetahuannya, tetapi anak memilih tahapan yang berbeda saat ia berada di tempat yang tidak dalam lingkungan tempat tinggalnya. Dengan demikian, dibutuhkan juga fungsi guru atau pendidik secara maksimal agar anak mampu memahami dan mengamati lebih dekat tentang perkembangannya.

\section{Analisis Teori Vygotsky}

Menurut teori Vygotsky bahwa anak yang masuk dalam proses perkembangan diawali dengan proses kesiapan dalam memasuki lingkungan sekolah. Setiap anak yang dalam proses perkembangan memiliki titik-titik yang berhubungan dalam keterampilan dan kemampuan sesuai dengan tingkat penguasaan yang berbeda. Dengan demikian setiap orang tua selalu membantu anak dalam proses kesiapan memasuki lingungan sekolah yang bertujuan untuk dapat menjadikan seorang anak yang memiliki pribadi yang mandiri.

Menurut Vygostky jika guru ingin mengetahui apa yang sudah siap dipelajari anak, kita tidak bisa melihat hanya pada apa yang bisa mereka lakukan saat bekerja sendirian, tetapi juga harus melihat jauh ke depan dan kemana ia akan berjalan saat diberikan sejumlah bantuan dari orang lain. Kontribusi terbesar pemikiran Vygotsky dibidang pendidikan adalah pentingnya kesadaran dalam pembelajaran, dalam pembahasan ini Vygotsky tidak menggunakan istilah tertentu, namun penelitiannya tentang bantuan memori dan konsep-konsep ilmiah menunjukkan cara-cara anak menjadi sadar akan pemikiran dan gagasan mereka sendiri, yang kemudian mulai melatih sejumlah pengendalian atas dirinya.

Menurut pandangan Vygotsky tentang anak TK yaitu setiap anak harus memulai sendiri terhadap pengetahuan, pemahaman dan pembelajaran mereka dan tidak terlepas dari peran orang tua maupun oang dewasa yang disekelilingnya yang berfungsi sebagai guru atau fasilitator dan moderator sangat berpengaruh bagi anak. Dalam pandangan diatas juga ditekankan bahwa perlu adanya keterlibatan orang dewasa, orang tua, dan keluarga yang melibatkan dalam proses pembelajaran seorang anak.

\section{Analisis Teori Bowbly}

Menurut Bowlby dengan teorinya yaitu attachment (melekat) menyatakan ada 4 tahap perkembangan pada anak usia dini. Pertama, fase pertama, respon tidak terpilah (usia lahir sampai 3 bulan). Pada fase ini bayi sangat menyukai wajah manusia dibandingkan dengan benda lainnya. Pada usia 0-3 bulan bayi selalu tersenyum kepada semua orang yang dilihatnya. Sikap ini menunjukkan kemelekatan bayi dengan semua ornag yang ada disekitarnya.

Fase kedua, fokus pada orang yang dikenal (usia 3-6 bulan). Pada tahap ini bayi lebih selektif dalam memberikan senyum. Mereka hanya tersenyum kepada orang-orang yang dikenalnya. Sikap ini menunjukkan kemelekatan bayi hanya dengan orang yang dikenalnya.

Fase ketiga, kemelekatan yang intens dan pencarian kedekatan yang aktif (usia 6 bulan sampai 3 tahun). Pada fase ini bayi selalu menangis jika ditinggalkan ibunya, dia menunjukkanrasa cemas terhadap perpisahan. Bayi akan menangis jika ditinggalkan dan akan tersenyum jika ibunya kembali.

Fase keempat, tingkah laku persahabatan (usia 3 tahun sampai akhir masa kanakkanak). Pada fase ini anak-anak berkosentrasi pada kebutuhan mereka untuk mempertahankan kedekatannya kepada orang tuanya atau pengasuhnya. Teori kemelekatan Bowlby menunjukkan bahwa manusia sejak anak-anak tidak bisa hidup sendirian sebagai makhluk sosial.

Perkembangan dan pertumbuhan anak dimulai dalam sejak kandungan, dan anak dikatakan hidup dimulai saat sel telur dibuahi oleh sel 
sperma. Dari satu sel yang dibuahi, kemudian membelah secara berulang kali yang menghasilkan ribuan, jutaan, bahkan milyaran sel. Dengan demukian, bentuk sel dan fungsi yang sama berkembang menjadi sel yang bersifat khusus seperti sel syaraf, sel otot, sel darah, sel tulang. Setiap sel tersebut akan membentuk jaringan, misalnya jaringan syaraf, jaringan otot, jaringan darah, jaringan epitel, dan juga jaringn tulang. Kemudian setiap sel yang membentuk jaringan aken membentuk organ baru, mislanya otak, jantung, mata, telinga, dan kaki. Organ tubuh memiliki proses perkembangan yang sangat pesat dimulai saat prenatal dalam perkembangan otak. Setiap sel syaraf otak mulai terbentuk saat usia kehamilan mulai tiga bulan pertama. Dengan demikian, bayi yang berusia kurang lebih 2-3 bulan yang mana ukuran kepala jauh lebih besar dari organ lainnya(Permono, 2013, p. 36). Perkembangan awal anak dimulai sejak dalam kandungan sehingga anak lahir ke dunia pun masih memiliki perkembangan dan pertumbuhan baik dari segi fisik maupun psikologis.

Terdapat beberapa faktor yang menyebabkan pertumbuhan dan perkembangan anak. Secara global, faktor tersebut dibagi menjadi 2 bahagian, yaitu faktor internal (dalam) dan faktor eksternal (luar/lingkungan). Pertumbuhan dan perkembangan akan berjalan dengan baik apabila terdapat kerjasama antara faktor internal dan eksternal yang maksimal. Faktor internal terdiri perbedaan ras, suku, dan bangsa. Selain faktor interal juga terdapat faktor eksternal yang mempengaruhi pertumbuhan dan perkembangan anak, seperti gizi, psikologis, dan sosial ekonomi (Chamidah, 2009).

Setiap pertumbuhan dan perembangan anak tidak lepas dari kerja sama. Seperti prinsipprinsip perkembangan yaitu bahwa seluruh aspek perkembangan saling bekerja sama antara satu sama lain yang memiliki tujuan ke arah yang positif, seperti motorik kasar dan motorik halus, kemampuan motorik halus mulai berkembang dan berfungsi dari sejak lahir dan berkembang secara bersamaan dalam tingkatan variasi sesuai dengan pengalaman kasus yang terdapat di lingkungan yang mempengaruhi kondisi fisik maupun lingkungan (Solihin et al., 2013, p. 70). Pendidik yang memiliki visi dan misi searah dalam proses perkembangan dan pertumbuhan akan menjadikan anak tumbuh dan berkembang kearah positif. Dengan demikian, pendidik dan orang tua harus memiliki tujuan kearah positif untuk menjadikan anak tumbuh dan kembang secara maksimal.

Berdasarkan dari pendapat tersebut, dapat diambil kesimpulan bahwa setiap perkembangan pada masa usia dini menjadi acuan dalam proses perkembangan yang akan datang menuju masa selanjutnya. Sehingga setiap proses perkembangan anak terealisasikan secara maksimal dengan fungsi dan tujuan paud yang telah ada. Menurut Piaget, Vygotsky teori kosntruktivistik, dan Bowbly difokuskan pada siswa yang pembelajaran dan penilian nya menggunakan autentik. Menurut Gardner dan Miller materi autentik dijadikan sebagai rujukan dalam pembelajaran autentik, dan materi autentik bisa didapat oleh semua orang dalam bentuk intrekasi (Nurkholida, 2018, p. 63). Terdapat sebuah rujukan dalam proses pembelajaran untuk anak menurut Gardner dan Miller yaitu pembelajaran autentik dimana materi pembelajaran autentik dapat diperoleh oleh semua orang khususnya dalam bentuk interaksi dengan orang lain. Dalam teori Piaget, Vygotsky dan Bowbly pembelajaran yang mendukung untuk anak adalah pembelajaran autentik.

\section{Peran Pendidik dalam Konsep Psikologi Perkembangan Anak}

Menurutt Iskardah dalam Mukti Amini, fungsi ibu bapak dalam proses perkembangan anak adalah sebagai berikut: a) memelihara kesahatan raga dan batin anak, b) menanamkan pondasi kepribadian yang baik, c) mengayomi dan memberikan dorongan anak untuk mengembangkan diri, d) memberikan fasilitas yang maksiaml dalam pengembangan diri anak, e) menciptakan suasana aman dan nyaman yang mendukung bagi perkembangan anak (Amini, 2015). Berdasarkan pendapat diatas, terlihat bahwa peran pendidik harus dijalankan dengan sesuai secara maksimal dan optimal dalam pertumbuhan dan perkembangan anak.

Menurut beberapa ahli pendidik, anak sangat dekat dalam pertumbuhan dan perkembangannya dilingkungan, baik lingkungan jasmani maupun lingkungan adat. Setiap orang yang berada dalam lingkungan 
anak sangat berperan dalam psikologi perkembangan anak. Apabila anak dilahirkan dalam lingkungan yang baik, maka ketika ia besar nanti mempunyai pengaruh besar dalam perkembangan menuju masa selanjutnya, begitu pula sebaliknya.

Sebagai fasilitator maka pendidik perlu untuk mengkondisikan lingkungan yang kondusif dan menantang untuk memenuhi rasa ingin tahu peserta didik sehingga proses pembelajaran dapat berlangsung secara efektif dan sesuai dengan kebutuhan(Mulyasa, 2007). Pendidik juga senantiasa membuat karyanya sendiri agar peserta didik ikut terinspirasi untuk membuat karyanya sendiri serta menjadikan suasana belajar mengajar sarat dengan pemberian inspirasi pada peserta didik. Peran guru sebagai pemberi inspirasi belajar (to giving learning inspiration), mempersyaratkan guru untuk mampu memerankan diri sebagai sosok yang memberikan inspirasi pembelajaran bagi peserta didik (inspiring teaching for student), sehingga kegiatan belajar dan pembelajaran dapat membangkitkan berbagai pemikiran, imajinasi, kreativitas, gagasan, dan ide-ide baru (I. Arifin, 2010; Mulyasa, 2007).

Pendidik dalam mengoptimalkan perkembangan dan pertumbuhan pada peserta didik sebagai kebutuhan dilakukan oleh pendidik agar proses belajar mengajar dapatpada peserta didik sebagai kebutuhan dilakukan oleh pendidik agar proses belajar mengajar dapat berlangsung dengan efektif. Dalam penerapan pembelajarannya, pendidik senantiasa memberikan fasilitas belajar atau lingkungan pembelajaran yang menyenangkan (joyfull learning) dan tidak membosankan bagi anak. Pendidik memiliki peran dalam memberikan kemudahan belajar (facilitate of learnin) kepada seluruh peserta didik, agar dapat belajar dalam suasana yang menyenangkan (joyfull) gembira (happy/fun), penuh semangat (morale/anthusias), tidak cemas (unnervous), dan berani mengemukakan pendapat (confident to open opinion) (Mulyasa, 2007).

\section{SIMPULAN}

Perkembangan dan pertumbuhan anak sangat berpengaruh dengan lingkungannya. Jika setiap perkembangan dan pertumbuhan seorang anak dapat berjalan lancar dan sesuai dengan tahapan perkembangan usianya, maka adanya peran pendidik yang mampu membantu dan mendukung secara penuh dalam setiap proses perkembangan anak secara optimal. Dalam konsep psikologi perkembangan terdapat teori Piaget, Vygotsky, dan Bowbly. y. Menurut teori Piaget, anak memiliki pemikiran secara praoperasional. Pada periode ini anak mampu mengembangkan tindakan yang baik dan terstruktur untuk menghadapi lingkungan, anak mulai memahami simbol yang digunakan dalam sebuah objek tertentu. Sedangkan menurut teori Vygostky perkembangan anak pada masa awal yang mengarah ke persiapan sekolah yang didasari oleh tipe hubungan yang dimiliki anak di daerah sosial nya yang berkdudukan pada perolehan tugas perkembangan, berdasarkan pendapat Vygotsky mengenai Zona Perkembangan Dekat yang memberikan contoh kerumitan relasi antara perkembangan dan pembelajaran yang berenergi dalam bentuk pergantian dari cara belajar yang intelektual bersama dengan cara masingmasing. Dan menurut Bowbly ada fase usia 3 tahun sampai akhir masa kanak-kanak, anak berkosentrasi pada kebutuhan mereka untuk mempertahankan kedekatannnya kepada orang tuanya atau pengasuhnya (termasuk pendidik).

\section{DAFTAR PUSTAKA}

Amini, M. (2015). Profil Keterlibatan Orang Tua dalam Pendidikan Anak Usia TK. Jurnal Ilmiah Visi, 10 (1), 9- 20.

Arifin, I. (2010). Kepemimpinan dan pendidikan karakter di Indonesia. Orasi ilmiah wisuda sarjana dan magister IKAHA Tebuireng Jombang. Panitia Wisuda IKAHA Tebuireng.

Arifin, S. (2016). Perkembangan Kognitif Manusia Dalam Perspektif Psikologi Dan Islam. Jurnal TADARUS 5, 5(1), 50-67.

Chamidah, A.N. (2009). Deteksi Dini Gangguan Pertumbuhan dan Perkembangan Anak. Jurnal Pendidikan Khusus, 4 (3), 83-93.

Depdikbud. (2014). Permendikbud Nomor 137 Tahun 2014 Tentang Standar Kompetensi. Jakarta: Departemen Pendidikan dan Kebudayaan.

Fakhruddin, A.U. (2010). Sukses menjadi Guru TK-PAUD. Jogjakarta: Bening.

Leikin, R., \& Dinur, S. (2011). Patterns of Flexibility: Teacher's Behavior in 
Mathematical Discussion. European Researchin Mathematics Education, 3, 111.

Mulyasa, E. (2007). Standar kompetensi dan sertifikasi guru. Bandung: PT Remaja Rosda karya Offset.

Nurkholida, E. (2018). Developing Authentic Material of Listening on Higher Education. Based On Constructive Learning Of Jean Piaget and Vygotsky Theory. OKARA: Jurnal Bahasa Dan Sastra, 12 (1), 59-74.

Patilima, H. (2015). Resiliensi Anak Usia Dini. Bandung: Alfabeta.

Paul, S. (2001). Teori Perkembangan Kognitif Jean Piaget. Yogyakarta: Kanisius.

Permono, H. (2013). Peran Orangtua Dalam Optimalisasi Tumbuh Kembang Anak Untuk Membangun Karakter Anak Usia Dini. Publikasi Ilmiah http://publikasiilmiah.ums.ac.id/handle/11 $617 / 3994$

Pratiwi, H., Ali, Yarliani, I., \& Ageng, D. (2017). Penyesuaian Konsep Matematika Dengan Perkembangan Kognitif Anak Usia Dini. Indonesian Journal of Islamic Early Childhood Education, 2 (1), 51-64.

Roopnarine, J. L., \& Johnson, J. E. (2015). Pendidikan Anak Usia Dini Dalam Berbagai Pendekatan. (Terjemahan) Jakarta: Prenamedia Group.

Santrock, Jhon W. (2011). Child Development (13th edition). New York: McGraw-Hill Companies.

Santrock, John W. (2010). Psikologi Pendidikan. Jakarta: Kencana Prenamedia Group.

Setiawan, E. (2014). Kamus Besar Bahasa Indonesia. Badan Pengembangan dan Pembinaan Bahasa.

Solihin, Malateki, R.D., Anwar, F., \& Sukandar, D. (2013). Kaitan Antara Status Gizi, Perkembangan Kognitif, dan Perkembangan Motorik Pada Anak Usia Prasekolah (Relationship Between Nutritional Status, Cognitive Development, and Motoric Development in Preschool Children). Penelitian Gizi Dan Makanan (The Journal of Nutrition and Food Research), 36 (1), 62-72.
Suyadi. (2010). Psikologi Belajar PAUD. Yogyakarta: PT Pustaka Insan Madani. 